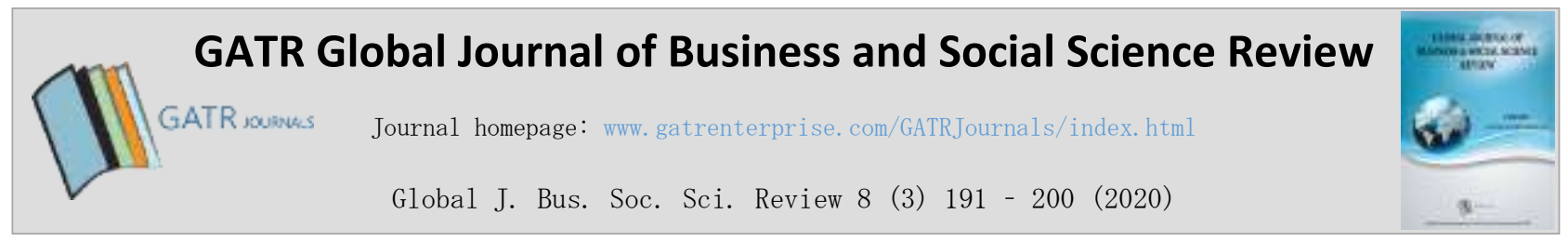

\title{
Conflict of multiracial to nationality decision making using exploratory factor analysis: Multiracial Thai-Japanese in Thailand
}

\author{
Thanapum Limsiritong ${ }^{1^{*}}$, Tomoyuki Furutani ${ }^{2}$, Karnjira Limsiritong ${ }^{3}$ \\ ${ }^{1,2}$ Keio university, 5322 Endo Kanagawa, 252-0882, Fujisawa, Japan \\ ${ }^{3}$ Siam University, 38 Petchkasame rd Bangwa Phasi Charoen, 10160, Bangkok, Thailand
}

\begin{abstract}
Objective - When a major problem in governance policies creates great difficulties for the development of the global community, this has an influence of society's awareness of concepts such as racism, discrimination and conflict issues which have an impact on the decision making process of future generations of multiracial and foreigner migrants. Identity of nationality can also be used to explain changes in the structure of a county. This research aims to: (1) study the variables of nationality decision making factors among multiracial Thai-Japanese groups in Thailand; (2) categorize the factor extraction of Exploratory Factor Analysis on nationality decision making of multiracial Thai-Japanese groups in Thailand; and (3) explore the relationships between important factors of nationality decision making factor units among multiracial Thai-Japanese groups in Thailand.

Methodology/Technique - There were 685 valid respondents obtained using an online purposive sampling questionnaire survey in acknowledgement of organizations (Bangkok, Chon Buri \& Chiangmai). The results indicate there are 3 factors of Thailand and 4 factors of Japan categorized for nationality decision making using exploratory factor analysis. Furthermore, the significance of each factor of Thailand and Japan affects nationality decision making. Finding - As a result of the binary logistic regression analysis, social structure, individual stability and country structure developments were identified as having a primary role in nationality decision making (Thai/Japanese/ and not decided or dual nationality).
\end{abstract}

Novelty - The results enable an understanding of the Thai and Japanese international community transformation and development from the perspective of nationality decision making.

Type of Paper: Empirical.

JEL Classification: O19, O20, O38

Keywords: Exploratory Factor Analysis; Thai-Japanese; Nationality Decision Making.

Reference to this paper should be made as follows: Limsiritong,T; Furutani, T; Limsiritong, K. (2020). Conflict of multiracial to nationality decision making using exploratory factor analysis: Multiracial Thai-Japanese in Thailand, Global J. Bus. Soc. Sci. Review, 8(3): 191 - 200. https://doi.org/10.35609/gjbssr.2020.8.3(6)

\section{Introduction}

Identity value and nationality status are typically very sensitive issues which have the ability to cause significant social and cultural issues within a community. Further, social awareness, racism, and discrimination are, still, major problems within the international community.

\footnotetext{
* Paper Info: Revised: July 26, 2020

Accepted: September 30, 2020

* Corresponding author: Thanapum Limsiritong

E-mail: thanapum@sfc.keio.ac.jp, thanapoom13@gmail.com

Affiliation: Graduate school of Media and Governance, Keio University, Japan
} 
Some countries such as Thailand and Japan gather data on the prevalence of these social attitudes and present their findings in an official report because of the complexity of their national policies and to raise social awareness of those issues. Meanwhile, the number of people who experience racism or discrimination of some kind usually increases with the number of long-stay tourists and refugees enter those countries, particularly through marriage to a national in the relevant country. According to the Tokyo Legal Affairs Bureau, Japan does not allow its citizens to hold dual citizenship. According to Japan Times (2019), a survey of 1,449 multiracial Japanese recipients in Japan showed that $76.8 \%$ refused to renounce their citizenship, 76.8\% were using 2 passports, and $93.2 \%$ thought that the national laws on dual citizenship should be amended. These issues ca have a significant impact on a given country as well as on the international community. In contrast, in Thailand a person is allowed to hold a dual citizenship subject to certain conditions. Furthermore, Japan's economic stability (or lack thereof) is one of the primary reasons why Japanese citizens emigrate to Thailand.

From 1954 to present, Japan and Thailand have been in alliance in most economic agreements. They have remained among the top 3 countries in almost the last 10 years in terms of investment in business, forming a manufacturing hub in South East Asia among SMEs in Thailand (BOI,2010-2019). The number of long-stay tourists in Thailand is now over 60,000 and the number of permanent residents is now over 15,000. This number is likely to double in the future (Japan Embassy, 2018); so too will the number of multiracial ThaiJapanese tourists. Hence, research regarding multiracial Thai-Japanese tourists living in Thailand is crucial for both the Thailand and Japanese governments.

The objectives of this study are:

To identify and examine the variables of nationality decision making factors among multiracial ThaiJapanese tourists in Thailand including push and pull factors in tourism and migration issues.

To categorize the factor extraction of Exploratory Factor Analysis on nationality decision making among multiracial Thai-Japanese groups in Thailand.

To explore the interaction between important factors of nationality decision making factors among multiracial Thai-Japanese tourists in Thailand.

The various Japanese Associations in Thailand and closed groups of Japanese societies online, long-stay agencies, and the Japanese Embassy in Thailand are acknowledged as providing vital support to this research by providing the research data for examination.

\section{Concept and Literature Review}

\subsection{Multiracial Concepts and Situations (Japan-Thailand)}

Identity is one of the seminal factors among multiracial groups. Identity includes:

Singular Identity: one nationality;

Boarder Identity: dual nationality;

Protean Identity: nationality could change in situations; and

Transcendent Identity: international citizenship.

(Rockquemore \& Brunsma, 2002)

The impact of multiracial identity may explain changes within a country both at a domestic and international level. The United Nations (2016) proposed that "It is now understood as a type of citizenship that transcends what is purely national, is unrelated to a specific identity and/or territory, and embraces a 
constantly evolving global ethic". This statement broadens the ideology of future societies and the problem of territory (state authorities) and global ethics who could become a future population in countries.

Moreover, family and community factors are the primary factors influencing self-identification (LaBarrie, 2017). Radina and Cooney (2000) found that when communities did not accept of one or all races, individual multiracial persons could suffer from not feeling accepted by their community and not having the opportunity to choose the nationality they wanted. In particular, safety concerns are a real risks factor for prevention between multiracial and monoracial communities (Choi, 2006). Japanese culture has recently experienced a transformation from homogenous to international due to the ageing population, labor shortages in both skilled and low skilled workers and international policies inviting foreigners to migrate to fill those gaps (Japan Times, 2019). Meanwhile, the number of migrant workers has increased across the last 10 years between 2006-2016 and the number of international marriages between foreigners and local residents have also increased.

Marriages between Thai migrants and Japanese citizens are now one of the top 4 marriages occurring in Japan (MHLW, 2016) which means that Thai-Japanese multiracial citizens will become dual citizens in Japan. Individuals can remain dual citizens until they reach the age of 22 according to the Nationality Act, which differs from Thailand where the ability to hold dual nationality is conditional. The issue of merged nationality is important to the development of identity, and the human rights of those people holding dual citizenship is a key interest among researchers and policy makers (Viager, 2011). Country policies could play a part of shaping societal attitudes and developments (Newland, 2017). As racial background grows in importance, policy makers should consider the societal impact this has on those holding dual citizenship, such as issues of racial vilification and discrimination (Pew Research Center, 2015). To address this issue, one must examine the impact of the current situation to identify the possibility of nationality issues that could lead to an increase in the prevalence of racism, discrimination.

\subsection{Tourism and Migration Concepts to Multiracial Factors}

The factors affecting tourism development include:

Political turmoil crisis

Epidemic disease

Economic fluctuation

Crime and drugs

Demographic changing

Language and technology

\section{(Thitthongkorn, 2010)}

In addition, the role of the government could play a part in security, public involvement and giving the control of community decisions (Ardahaey, 2010). Further, a statement of migration development has been proposed by the Migration Policy Institute (2020) as follows:

Governance structure for country growth and stability status.

Migrant protection standards.

Global governance and state cooperation.

Frameworks for migrant return and reintegration.

Moreover, education could support growing diversity in the homogenous perspective (Maruyama, 2019). The same perspective of tourism and migration are involved with acceptance of international race and social diversity. Nevertheless, push and pull concepts have been used to identify the two sides of the negative

Global J. Bus. Soc. Sci. Review 8 (3) 191 -200 (2020) 
(push) and positive (pull) probability of situations. Studying tourism push and pull factors focuses on strengthening the possibility of migrants revisiting a country while migration focuses on increasing opportunity, labor, society, economics, political and returning possibility (Mohammad, 2010). The time that a migrant remains in a destination county could possibly be extended if they wish to remain in that destination for leisure of further opportunities. Asako Kajiura (2008) proposed that the push and pull factors of Japanese migrants fall within 4 broad categories, being:

economic conditions

education

cultural change

social structure change

It is clear that the perspective of the international community requires the integration of a country's own system, governance system, social system, and individual cooperation (Renn, 2008). Furthermore, the definition of 'mixedness society' is to be adjusted to cross-disciplinary research because it is impractical for a person to choose their identities easily, flexibly in the equal rights and context situations (Törngren, 2019). In 1990, multiracial status became an important issue in the US Government. Minority change could impact immensely on country management and consumption systems (Williams, 2017) In terms of governance, global governance in the third sphere is grounded in both bilateral and multilateral engagements which demonstrates the need to determine a global policy of 'national interest' (Maley, 2016). Multiracial race could be a big factor of future populations, meaning studying this group is integral to the transformation of each country both domestically and internationally.

\section{Research Methodology}

\subsection{Sampling Selection and Data Collection Tools}

A quantitative method was used to collect the data online between December 2019 to April 2020 from the top 3 destination (Bangkok, Chon Buri, and Chiangmai) according to the Japan long-stay statistics from the Japanese Embassy in Thailand, 2019. In particular, the majority of Thai nationals living in Japan were from Bangkok (53,000 out of 73,000, being approximately $72.6 \% \approx 73 \%$ ). Bangkok was the main area of focus in this paper. There were $(n)=685$ valid respondents in this research according to Cochran (1953) sampling size to the infinite population of $95 \%$ confidence level of $e=.05$ to $n=449$ in the minimum of sampling. There is no data on multiracial or international marriage from the Thailand government official statistics so, an infinite population was used in the sample size.

Purposive sampling was used to choose sampling in specific conditions, including:

Thai-Japanese multiracial citizens aged 18 years and over

Living in Thailand and having a resident place in Japan

Having a Japanese mother/father and/or a relative in Thailand

Having or previously having experience living in Japan for purposes such as working, visiting friends and relatives, and studying

In addition, the item in the questionnaire for each item was between .60-1.0 which passed the standard of .50 of IOC validity score. The pilot questionnaire from the first attempt of 60 respondents was collected to test the reliability of the Cronbach alpha; the score passed the standard score $\alpha=.816$. Moreover, the questionnaire was comprised of 4 parts:

Demographic data 
Background of living in Thailand and Japan

Consideration of living in Thailand $(\alpha=.949: 26$ items in 7 Likert scales : $1=$ strongly disagree to $7=$ strongly agree) and Japan ( $\alpha=.952: 26$ items in 7 Likert scales : $1=$ strongly disagree to $7=$ strongly agree $)$

Returning reasons and opinions

Furthermore, all of the information of the respondents was used only in this research. Appropriate anonymity and security measures were used.

\section{Results and Discussion}

\subsection{Demographic Understanding of Respondents}

The results show that $41.2 \%$ of the respondents were male and $58.8 \%$ were female. The vast majority of the respondents are aged between $24-41$ years old. $41.6 \%$ of the respondents were single whilst $34.2 \%$ were married to a Thai national, $14 \%$ to a Japanese national and $6.7 \%$ to other nationalities. The education level shows to the majority of the respondents graduated in high education level of bachelor's and master's degree $(83.8 \%)$. The occupation presents to over $60 \%$ working in a skilled labor level such as Officer Manager, skilled worker, and business owner (13.7\%). The range of salary among the respondents is between 45,000 to 250,000 (52.4\%). Furthermore, the Japanese first generation in Thailand in their family found that $38.1 \%$ are Japanese mothers, followed with Japanese fathers at $28.9 \%$. Further, $95.3 \%$ have their principal place of residence in Japan whilst 100\% have had an experience in Japan for a moment in time. Additionally, 97.7\% use Thai language for communication, $85.7 \%$ are able to communicate in Japanese and $85.1 \%$ are able to communicate in English. Lastly, the possibility to return to Japan by reasoning found that $74.6 \%$ never thought about returning to Japan permanently, $49.6 \%$ returned for family reasons, $37.5 \%$ returned for relationship reasons, $27.7 \%$ returned for business reasons, $19.6 \%$ returned for education reasons and $12.6 \%$ returned for health reasons.

\subsection{Nationality Decision Making on Exploratory Factor Analysis Results}

There are 52 items to the indicators which are separated into 26 items for both Thailand and Japan. An extraction method of Principal Component Analysis and rotation method of Varimax with Kaiser Normalization is applied to both groups. The results identified 3 component factors ( 15 items out of 26 items) of Thailand and 4 component factors (19 items out of 26 items) of Japan which all have communality (C.) $>.30=$ acceptable to use the item in EFA. Following the extraction of the component, the factor loading (FL.) are chosen $>0.6$ in each item. Lastly, indicator units are grouped into factors and names which affects nationality decision making differently.

The results of the Thailand Exploratory Factor Analysis are presented KMO. .919 (value between 0.8 closest to 1 are adequate) and Bartlett's test .000 at the significant level which means they are acceptable to use in the Principal Component Analysis. This can explain the variance of $64.514 \%$ from 3 component factors and the factor loading between .602 to .864 . Specifically, the component 1 has $\alpha=.921$ (>.70 is acceptable) E.V. $=12.747$ and variance $=49.027 \%$, it is comprised of 7 items and constructed the name of "Structure macro issues concerned". The component 2 has $\alpha=.902(>.70$ is acceptable) E.V. $=2.352$ and variance $=9.046 \%$, it is comprised of 6 items and constructed the name of "Social safety concerned". Lastly, the component 3 has $\alpha=.718$ (>.70 is acceptable) E.V. $=1.675$ and variance $=6.442 \%$, it is comprised of 2 items and constructed the name of "Individual stability concerned".

The results of the Japan Exploratory Factor Analysis are presented KMO. .897 (value between 0.8 closest to 1 are adequate) and Bartlett's test .000 at significant level which means it is acceptable to use in the Principal Component Analysis. This can explain the variance of $68.144 \%$ from 4 component factors and the factor loading between .632 to .856 . Specifically, the component 1 has $\alpha=.781$ (>.70 is acceptable) E.V. = 
12.106 and variance $=46.560 \%$, it is comprised of 7 items and constructed the name of "Social macro issues concerned". The component 2 has $\alpha=.900$ (>.70 is acceptable) E.V. $=2.357$ and variance $=9.065 \%$, it is comprised of 6 items and constructed the name of "Social safety concerned". The component 3 has $\alpha=.818$ $(>.70$ is acceptable) E.V. $=1.776$ and variance $=6.831 \%$, it is comprised of 3 items and constructed the name of "Individual stability concerned". Lastly, the component 4 has $\alpha=.757$ ( $>.70$ is acceptable) E.V. $=1.479$ and variance $=5.688 \%$, it is comprised of 3 items and constructed the name of "Structure macro issues concerned".

Table 1. Thailand and Japan Principal Component Analysis (EFA.) results.

\begin{tabular}{|c|c|c|c|}
\hline \multicolumn{2}{|c|}{ Thailand: Principal Component Analysis } & \multicolumn{2}{|c|}{ Japan: Principal Component Analysis } \\
\hline $\begin{array}{c}\text { KMO. .919 } \\
\text { Bartlett's Test of Sphericity } \\
\text { Appox.Chi-Square } 16804.385 \\
\text { df } \quad 325 \\
\text { Sig. .000 } \\
\text { Vr. }=64.514 \%\end{array}$ & & $\begin{array}{c}\text { KMO. } .897 \\
\text { Bartlett's Test of Sphericity } \\
\text { Appox.Chi-Square } 16418.548 \\
\text { df } \quad 325 \\
\text { Sig. .000 } \\
\text { Vr. }=68.144 \% \\
\end{array}$ & \\
\hline 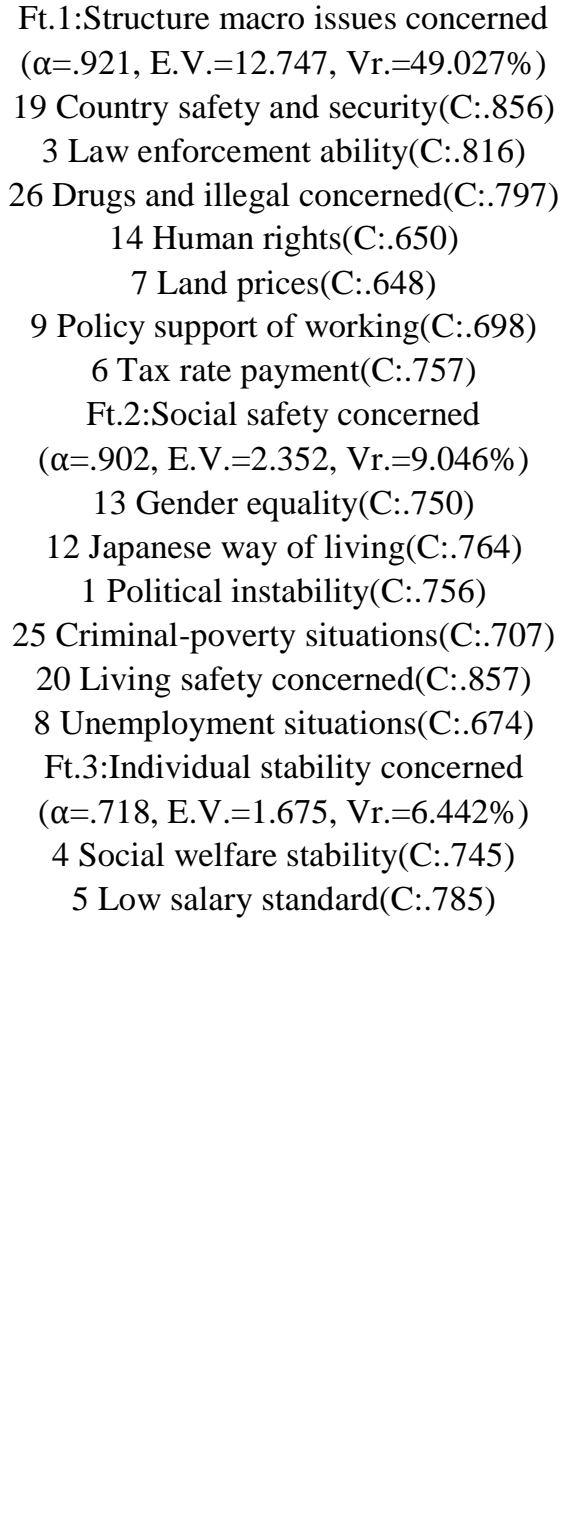 & $\begin{array}{l}\text { FL. } \\
.864 \\
.853 \\
.841 \\
.693 \\
.670 \\
.643 \\
.615\end{array}$ & 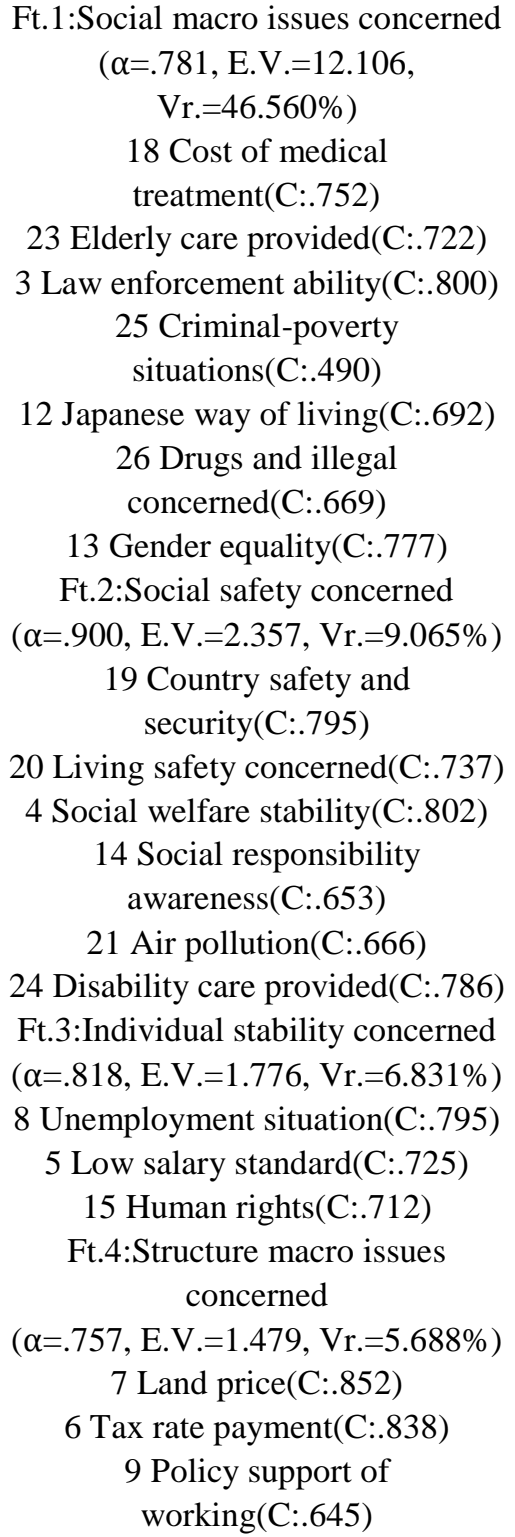 & $\begin{array}{l}\text { FL. } \\
.817 \\
.665 \\
.665 \\
.653 \\
.651 \\
.634 \\
.632\end{array}$ \\
\hline
\end{tabular}

*(SPSS version 25) : KMO.=Kaiser-Meyer-Olkin Measure of Sampling Adequacy , $a=$ Alpha Cronbach , E.V.=Eigen value , Vr.=Variance , C. =communality , Ft.=Factor , FL.=Factor loading 


\subsection{Influence of Binary Logistic Regression on Nationality Decision Making}

The results show that there are 3 groups who decided to choose (1) Thai, (2) Japanese, and (3) Have not decided yet (Dual nationality). Moreover, the full indicators from the Thailand and Japan EFA results are statistically significant at 0.00 in the Omnibus tests.

Table 2. Thailand and Japan influence indicators results

\begin{tabular}{|c|c|c|c|c|}
\hline $\begin{array}{l}\text { Decision } \\
\text { making }\end{array}$ & \multicolumn{2}{|c|}{ Thailand indicator in concerned } & \multicolumn{2}{|c|}{ Japan indicator in concerned } \\
\hline \multirow{19}{*}{$\begin{array}{c}\text { Thai } \\
\text { THA=0 } \\
\text { Other }=1\end{array}$} & FT1. & \multirow{3}{*}{$\begin{array}{c}.000 \\
\text { omnibus test }\end{array}$} & FT1. & \multirow{3}{*}{$\begin{array}{c}.000 \\
\text { omnibus test }\end{array}$} \\
\hline & Human rights & & Japanese way of living & \\
\hline & Sig.004 / $\operatorname{Exp}(B) 1.452$ & & Sig.026 / $\operatorname{Exp}(B) .762$ & \\
\hline & Tax rate payment & \multirow{2}{*}{$\begin{array}{c}.071 \\
\text { Cox\&Snell }\end{array}$} & Elderly care provided & \multirow{2}{*}{$\begin{array}{c}.135 \\
\text { Cox\&Snell }\end{array}$} \\
\hline & Sig.016 / $\operatorname{Exp}(B) 1.367$ & & Sig.034 / Exp(B).631 & \\
\hline & Law enforcement ability & \multirow{3}{*}{$\begin{array}{l}.140 \\
\text { Nagelkerke }\end{array}$} & FT2. & \multirow{3}{*}{$\begin{array}{c}.267 \\
\text { Nagelkerke }\end{array}$} \\
\hline & Sig.024 / Exp(B).677 & & Social welfare stability & \\
\hline & FT2. & & Sig.000 / $\operatorname{Exp}(B) 2.084$ & \\
\hline & $\begin{array}{c}\text { Political instability } \\
\text { Sig.004 / } \operatorname{Exp}(B) 1.509\end{array}$ & \multirow{11}{*}{$\begin{array}{c}88.9 \% \\
\text { correctly } \\
\text { classified }\end{array}$} & $\begin{array}{c}\text { Social responsibility } \\
\text { awareness }\end{array}$ & \multirow{11}{*}{$\begin{array}{l}90.7 \% \\
\text { correctly } \\
\text { classified }\end{array}$} \\
\hline & Living safety concerned & & Sig.048/ $\operatorname{Exp}(B) 1.257$ & \\
\hline & Sig.000 / Exp(B) .499 & & Disability care provided & \\
\hline & FT3.-none & & Sig.004 / Exp(B).458 & \\
\hline & & & FT3. & \\
\hline & & & Human rights & \\
\hline & & & Sig.013 / $\operatorname{Exp}(B) 1.432$ & \\
\hline & & & FT4. & \\
\hline & & & Land price & \\
\hline & & & Sig.004 / $\operatorname{Exp}(B) 2.400$ & \\
\hline & & & $\begin{array}{c}\text { Tax rate payment } \\
\text { Sig.007 / } \operatorname{Exp}(B) .453\end{array}$ & \\
\hline \multirow{19}{*}{$\begin{array}{l}\text { Japanese } \\
\mathrm{JP}=0 \\
\text { Other }=1\end{array}$} & FT1. & \multirow{2}{*}{$\begin{array}{c}.000 \\
\text { omnibus test }\end{array}$} & FT1. & \multirow{3}{*}{$\begin{array}{c}.000 \\
\text { omnibus test }\end{array}$} \\
\hline & Country safety and security & & Drugs and illegal concerned & \\
\hline & Sig.010 / Exp(B) 2.919 & \multirow[b]{2}{*}{$\begin{array}{c}.151 \\
\text { Cox\&Snell }\end{array}$} & Sig.004 / Exp(B)7.016 & \\
\hline & $\begin{array}{c}\text { Land price } \\
\text { Sig.018 / } \operatorname{Exp}(B) 2.102\end{array}$ & & $\begin{array}{l}\text { Cost of medical treatment } \\
\text { Sig.021 / } \operatorname{Exp}(B) 3.326\end{array}$ & $\begin{array}{c}.180 \\
\text { Cox\&Snell }\end{array}$ \\
\hline & FT2. & \multirow{3}{*}{$\begin{array}{l}.509 \\
\text { Nagelkerke }\end{array}$} & Gender equality & \multirow{3}{*}{$\begin{array}{c}.608 \\
\text { Nagelkerke }\end{array}$} \\
\hline & Japanese way of living & & Sig.005 / Exp(B).331 & \\
\hline & Sig.000 / Exp(B)3.298 & & Law enforcement ability & \\
\hline & Living safety concerned & \multirow{12}{*}{$\begin{array}{c}96.5 \% \\
\text { correctly } \\
\text { classified }\end{array}$} & Sig.025 / Exp(B).169 & \multirow{12}{*}{$\begin{array}{l}95.5 \% \\
\text { correctly } \\
\text { classified }\end{array}$} \\
\hline & Sig.010 / $\operatorname{Exp}(B) 2.328$ & & FT2. & \\
\hline & $\begin{array}{c}\text { Gender equality } \\
\text { Sig.039 / } \operatorname{Exp}(B) .466\end{array}$ & & $\begin{array}{c}\text { Country safety and security } \\
\text { Sig.030 / } \operatorname{Exp}(B) 3.396\end{array}$ & \\
\hline & FT3. & & Air pollution & \\
\hline & Social welfare stability & & Sig.026 / Exp(B)2.537 & \\
\hline & Sig.013 / $\operatorname{Exp}(B) .301$ & & Living safety concerned & \\
\hline & Low salary standard & & Sig.001 / $\operatorname{Exp}(B) .015$ & \\
\hline & Sig.000 / Exp(B) .091 & & FT3.-none & \\
\hline & & & FT4. & \\
\hline & & & Tax rate payment & \\
\hline & & & Sig.000 / Exp(B)41.522 & \\
\hline & & & Policy support of working & \\
\hline
\end{tabular}




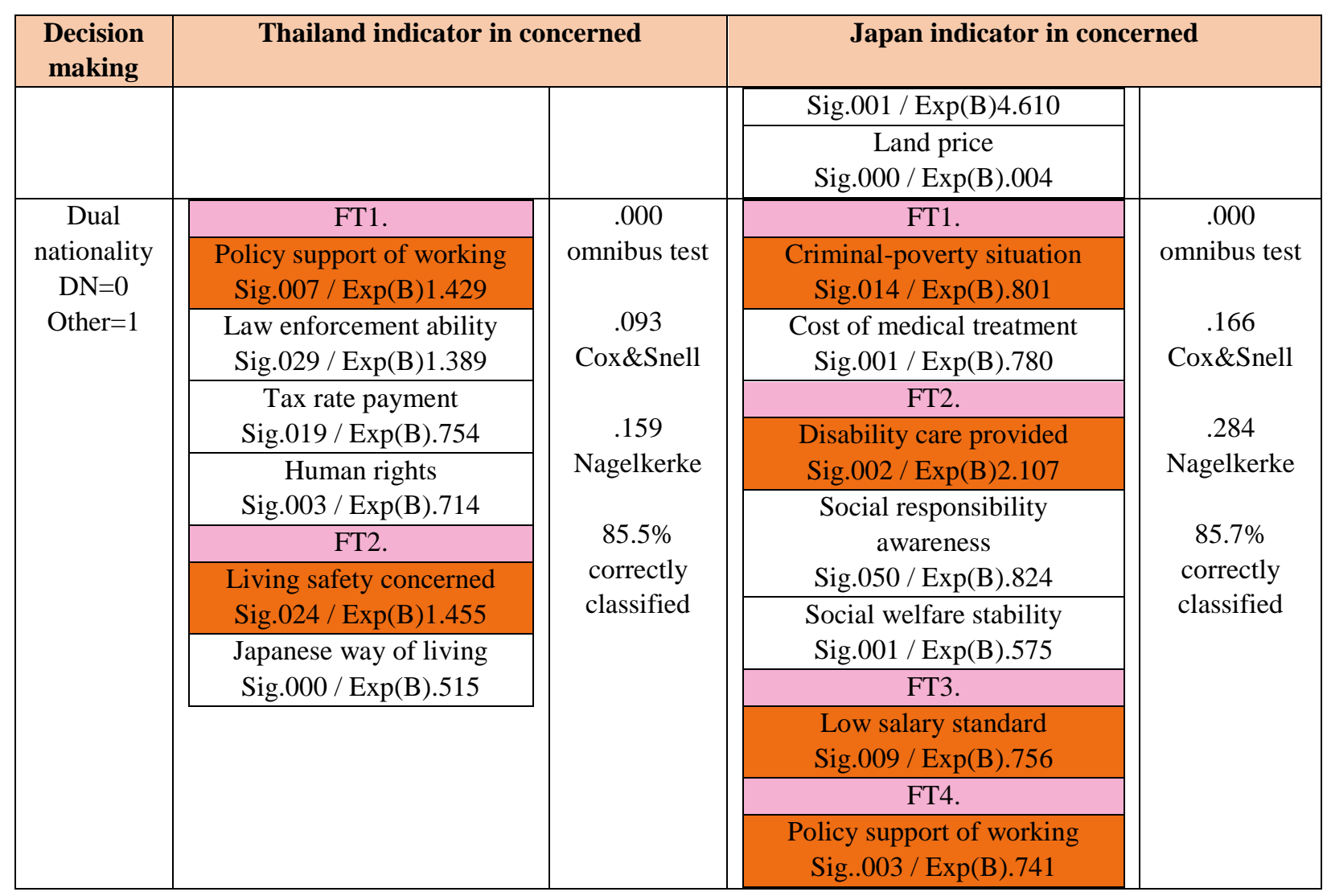

\section{Conclusion}

The descriptive statistics show that the social status of living by working and salary wage is higher than the standard of local people in Thailand, meanwhile, the primary reason for return to Japan is the possibility of losing future populations in Japan because of the complexity in Japan's legal system. The different contexts of Thailand and Japan result in a wide range of different factors and variables. These factors can explain and generate from top to down country structure which is political and governance issues, economy and stability, working environment, society and culture, hospital and treatment, and country problems to human development. A big picture of exploratory factor analysis shows the benefits of government approaches and can be used to construct and possibility highlight macro issues among both society and individuals. The exploratory factor analysis indicates the possible factors that can be used to understand and integrate support and enhance government approaches to policy in this area and to raise international awareness of these issues. Likewise, binary logistic regression analysis indicates the possibility of each factor unit to interact with nationality decision making probability. The trend of factor units tends to expand from social structure and individual stability which is relevant to country structure development issues.

In terms of decision making for dual nationals in Thailand, policy support of working and living safety concerns are most important. Likewise, criminal-poverty, disability care (health care systems), low salary standards, and policy support for workers are of the highest concern in Japan.

The transformation to future societies with international citizenship (mixedness globally) is dependent on the many structures from the top to down. These macro issues and safety concerns need to be addressed in both Thailand and Japan. This is important to improve the standard of living for multicultural citizens living both domestically and internationally and could be integral to the push and pull factors contributing to the movement of international travelers around the globe, which has a flow on effect on global economies.

Previous studies have tried to identify the factors contributing to discrimination of multiracial citizens. In this paper, the results identify key macro issues and individual factors which could be the fundamental root of 
inequality. If the state provides services equally to all citizens with safety and security as their main concern, this could have a considerable positive impact on the development of their community both domestically and internationally. This could also reduce inequality and conflict between monoracial (local) and multiracial communities. Future research should address approaches to other multiracial nationalities by using confirmatory factor analysis in the development of current issues and qualitative research to develop a model for a deeper understanding of these issues.

\section{References}

Tohidy Ardahaey, F., \& Haydaryzadeh, E. (2010). Factors Affecting the Development of Tourism Industry in Iran. Available at SSRN 1622603. http://dx.doi.org/10.2139/ssrn.1622603

BOI(Thailand Board of Investment). (2019). Annual report 2018. Retrieved from https://www.boi.go.th/upload/report/2561/index.html

Japan Times. (2019). Japanese cities worried about taking in more foreign workers, survey finds. https://www.japantimes.co.jp/news/2019/02/10/national/japanese-cities-worried-taking-foreign-workers-surveyfinds/\#.XtkXnZ4zbYU

Kajiura, A. (2008). The Push-Pull Factors of Japanese Migration. Polyglossia. 10(15). 11-24. https://secure.ritsumei.ac.jp/rcaps/uploads/fckeditor/publications/polyglossia/Polyglossia_V15_Kajiura.pdf

Williams, K. M. (2017). The Recursive Outcomes of the Multiracial Movement and the End of American Racial Categories. Studies in American Political Development, 31(1), 88. DOI: 10.1017/S0898588X17000074

LaBarrie, T. L. (2017). IDENTITY DEVELOPMENT. http://www.familyinstitute.org/sites/default/files/pdfs/multiracial_identity_development.pdf

Maruyama,H. (2019). Challenges for immigrants in formal and informal education settings in Japan.

Japan International Cooperation Agency (pp.1-17). Global Education Monitoring Report. https://issuu.com/unpublications/docs/education_monitoring_report

Newland, K., \& Riester, A. (2017). Towards a Global Compact for Migration: A Development Perspective. https://www.migrationpolicy.org/programs/international-program/global-compact-migration

Ministry of Health, Labour and Welfare. (2016). Annual Health, Labour and Welfare Report 2016. https://www.mhlw.go.jp/english/wp/wp-hw10/index.html

Mohammad, B. A. M. A. H., \& Som, A. P. M. (2010). An analysis of push and pull travel motivations of foreign tourists to Jordan. International Journal of Business and Management, 5(12), 41. https://pdfs.semanticscholar.org/cd93/2a25de7dedabe403d6cf09621dc6e03fd55f.pdf

Newland, K. (2017). Migrant Return and Reintegration Policy: A Key Component of Migration Governance. Migration Research Leaders' Syndicate, 169. https://publications.iom.int/system/files/pdf/migration_research_leaders_syndicate.pdf\#page=177

Parker, K., Morin, R., Horowitz, J. M., Lopez, M. H., \& Rohal, M. (2015). Multiracial in America: Proud, diverse, and growing in numbers. Washington, DC: Pew Research Center, 98, 109. https://www.pewsocialtrends.org/wpcontent/uploads/sites/3/2015/06/2015-06-11_multiracial-in-america_final-updated.pdf

Radina, M. E., \& Cooney, T. M. (2000). Relationship quality between multiracial adolescents and their biological parents. American Journal of Orthopsychiatry, 70(4), 445-454. https://doi.org/10.1037/h0087763

Renn, K. A. (2008). Research on biracial and multiracial identity development: Overview and synthesis. New Directions for Student Services, 2008(123), 13-21. https://doi.org/10.1002/ss.282

Rockquemore, K. A., \& Brunsma, D. L. (2002). Socially embedded identities: Theories, typologies, and processes of racial identity among Black/White biracials. Sociological Quarterly, 43(3), 335-356. https://doi.org/10.1111/j.15338525.2002.tb00052.x

Thitthongkam, T., \& Walsh, J. (2011). An analysis of factors influencing the competitiveness of the Thai tourism industry. In International Conference on Business and Economics Research (Vol. 1, pp. 138-141). https://www.academia.edu/download/30876032/30-B10007.pdf

Törngren, S. O., Irastorza, N., \& Rodríguez-García, D. (2019). Understanding multiethnic and multiracial experiences globally: towards a conceptual framework of mixedness. https://doi.org/10.1080/1369183X.2019.1654150

United Nation. (2016). Global Citizenship: A New and Vital Force.

https://www.un.org/en/chronicle/article/global-citizenship-new-and-vital-force 
Viager, A. (2011). Multiracial identity development: Understanding choice of racial identity in Asian-White college students. Journal of the Student Personnel Association at Indiana University, 38-45. https://scholarworks.iu.edu/journals/index.php/jiuspa/article/view/1937

Maley,W. (2016). What is a Refugee?. Bell \& Bain Ltd, Glasgow, United Kingdom, ISBN 9781849046794. pp121.

Choi, Y., Harachi, T. W., Gillmore, M. R., \& Catalano, R. F. (2006). Are multiracial adolescents at greater risk? Comparisons of rates, patterns, and correlates of substance use and violence between monoracial and multiracial adolescents. American Journal of Orthopsychiatry, 76(1), 86-97. https://doi.org/10.1037/0002-9432.76.1.86 